Journal of Sea Research

September 2018, Volume 139 Pages 1-9

http://dx.doi.org/10.1016/i.seares.2018.05.010

http://archimer.ifremer.fr/doc/00441/55261/

(c) 2018 Elsevier B.V. All rights reserved.

\title{
Underwater video offers new insights into community structure in the Grande Vasière (Bay of Biscay)
}

\author{
Mérillet Laurène ${ }^{1,2,{ }^{*}}$, Robert Marianne ${ }^{2}$, Salaun Michèle ${ }^{2}$, Schuck Lucie ${ }^{2}$, Mouchet Maud ${ }^{1}$, \\ Kopp Dorothée ${ }^{2}$
}

${ }^{1}$ Centre d'Ecologie et de Sciences de la Conservation, UMR 7204 MNHN-SU-CNRS, 43 rue Buffon,
Paris 75005 , France
2 Unité de Sciences et Technologies halieutiques, Laboratoire de Technologie et Biologie Halieutique,
Ifremer, 8 rue François Toullec, Lorient 56100 , France

* Corresponding author : Laurène Mérillet, email address : laurene.merillet@gmail.com

\begin{abstract}
:
Based on towed underwater videos, diversity patterns and their main environmental and anthropogenic drivers were assessed in the "Grande Vasière" (northeast Bay of Biscay), one of the main French fishing grounds. The density of bentho-demersal megafauna was recorded along 152 transects in this area in 2014. The highest number of taxa and densities were observed on the external margin of the Grande Vasière, in deep areas with low fishing intensity. The highest levels of taxa evenness were located on the central and coastal parts that are shallower and exposed to medium to high trawling intensity. Multivariate analysis identified four different communities driven by fishing intensity, depth, sediment type and bottom current speed. We distinguished three communities in the centre of the Grande Vasière covered by medium to highly trawled soft sediments and characterized by Hydrozoa, Crustacea such as Munida rugosa, Nephrops norvegicus and Goneplax rhomboides and Actinopterygii unidentified. A fourth community was identified on the external margin, deeper, undergoing lower trawling intensity than the other communities and dominated by sessile filter feeders. The fragile taxa observed in this study had almost always been unobserved by from previous studies using scientific trawl sampling. Underwater video thus allowed collecting unprecedented data by direct visualization of the seabed and the observation of fragile taxa that cannot be effectively sampled by traditional scientific sampling methods used in previous studies.
\end{abstract}

\section{Highlights}

- Diversity patterns of the Bay of Biscay were assessed based on underwater video data. Underwater video enabled the observation of species usually poorly sampled by trawl. richness and density were higher on the external margin of the area. The four communities identified were driven by fishing, depth, sediment and current.

Keywords : Biodiversity patterns, Indicator species, Fishing and environmental variables 


\section{INTRODUCTION}

In the context of the implementation of the Ecosystem Approach to Fisheries Management, the impacts of human activities on seabeds and their communities are of growing concern. In France, the Marine Strategy Framework Directive (2008) aims to achieve a good ecological status, characterised notably by the level of biological diversity (descriptor 1) and the integrity of the seabed (descriptor 6). It is thus of particular interest to describe bentho-demersal communities and understand the impacts of fishing activities on both commercial and non-commercial species as well as on the physical structure of the habitat. Traditional scientific trawl, dredge or grab sampling alone does not provide information on the structure of the habitat and poorly samples fragile species (Auster et al. 2011; ICES 2016). Conversely, underwater video enables a direct visualization of the seabed over large areas, of an order of magnitude of one hundred square metres (Mallet \& Pelletier 2014; Sheehan et al. 2016), leading to a better accuracy in the evaluation of abundance and taxonomic richness (Hewitt et al. 2011; Buhl-Mortensen et al. 2015). Underwater video provides information on the distribution of species, particularly the most fragile ones like Pennatulacea. In addition to biological data, this method makes it possible to collect abiotic data, such as the type of sediment surface, small-scale topography, trawl marks as well as more general information on the seabed landscape, e.g., the position of a species in its environment, relative to the bottom or other features of the seascape such as rocks.

In the northeast Atlantic shelf area, as in most shelf ecosystems, the variables identified as the main factors controlling benthic macro and megafauna distribution are depth, sediment type, temperature, salinity and water movement patterns (Bremner et al. 2006; Vaz et al. 2007; Serrano et al. 2008; Hily et al. 2008; Martins et 
al. 2013). Most of the continental shelf areas in the northeast Atlantic are active fishing grounds (Eigaard et al. 2016) and fishing activities have also been shown to be an important abiotic driver of species distribution (Jennings and Kaiser 1998).

The area known as the "Grande Vasière" in the northeastern Bay of Biscay, is one of the major French fishing grounds. While a few studies have investigated the biodiversity over this area (Glémarec 1969; Poulard et al. 2003; Blanchard et al. 2004; Hily et al. 2008; Le Loc'h et al. 2008), a comprehensive assessment of the composition and distribution of communities in relation to a wide range of environmental variables is still lacking.

The relative importance of abiotic variables in structuring communities varies with the scale considered, with seabed morphology expected to be important at a small scale, but depth, salinity, temperature and current considered to have more influence on communities at a larger scale (Bremner et al. 2006; Sell and Kröncke 2013). In this study, the large number of underwater video transects sampled over the Grande Vasière made it possible to obtain data at a scale appropriate for identifying the influence of fishing (Gray et al. 2006), depth, salinity, temperature and current on the distribution of diversity patterns.

This study, based on a method making it possible to access unprecedented information on the distribution of bentho-demersal megafauna, aims to (1) establish biodiversity patterns in the Grande Vasière, (2) depict community structure and indicator taxa, and (3) identify the main environmental and anthropogenic drivers of communities. 


\section{METHODS}

\subsection{Sampling area}

The Grande Vasière Nephrops fishing ground is located on the continental shelf, in the northeastern Bay of Biscay. This area covers around $12000 \mathrm{~km}^{2}$ and stretches from Penmarc'h cape $\left(47^{\circ} 48 \mathrm{~N}\right)$ to Rochebonne cape $\left(46^{\circ} 10 \mathrm{~N}\right)$ (Hily et al. 2008). Characteristics of the substratum were extracted from Bouysse et al. (1986) that released a map of sediment types in the Bay of Biscay, based on grabs samplings. The substratum (Fig. 1A) is composed of soft sediments classified into five types: (1) mud, i.e., fine sediments containing more than $75 \%$ fine mud; (2) sandy mud, containing more than $25 \%$ fine mud; and three types of muddy sands (3) lithoclastic muddy sand, (4) carbonate muddy sand and (5) calcareous muddy sand. Calcareous and, to a lesser extent, carbonated sediments are characterised by a higher $\mathrm{CaCO} 3$ content than the other sediment types (see Mérillet et al. 2018 for more details on these sediment types). Depth ranged from $66 \mathrm{~m}$ to $133 \mathrm{~m}$ (Fig. 1B). Mean annual current speed, temperature and salinity were extracted from the MARS3D model (Lazure et al. 2009) for the year 2014 (Fig. 1C, 1D and 1E). 

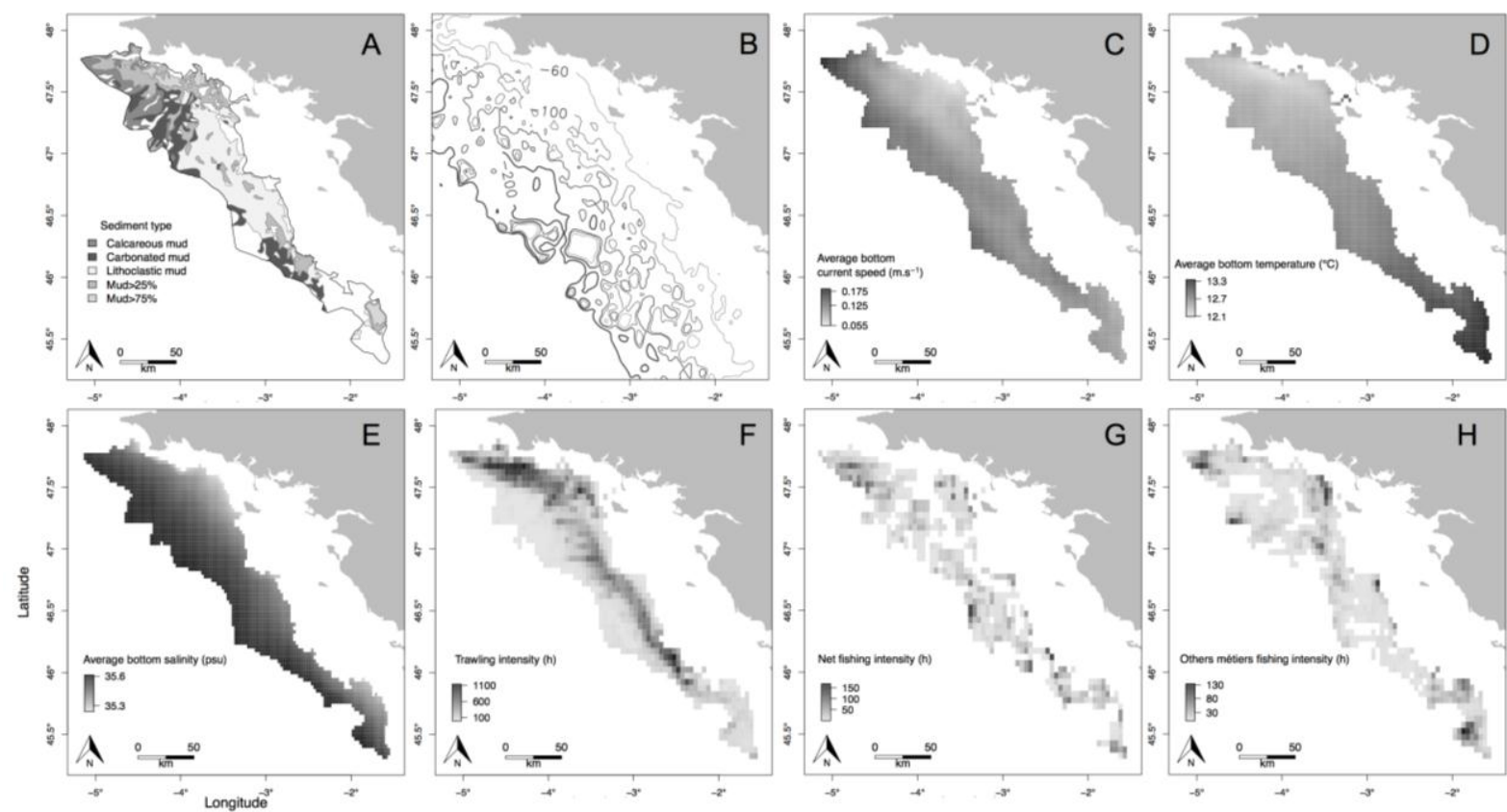

Figure 1: Environmental and fishing intensity variables over the studied area: sediment type $(A)$, depth $(B)$, average annual current speed at the bottom (C), average annual temperature at the bottom (D), average annual salinity at the bottom $(E)$, trawling intensity $(F)$, net fishing intensity $(G)$ and other métiers fishing intensity $(H)$ in fishing hours summed over the Nephrops fishing season (beginning of April to the end of September 2014).

\subsection{Data collection}

Sampling was conducted on board the R/V Celtic Voyager in September 2014. A total of 152 transects were carried out where video of the seabed was recorded using a camera fixed on a sledge which was lowered onto the seabed and towed behind the vessel at an average speed of 0.85 knots for 10 min. The location of transects was determined within the geographical limits of the Grande Vasière according to a regular square grid of $8.7 \times 8.7 \mathrm{~km}$ resolution, built from a first point chosen at random (i.e. a randomised square grid) following Lordan et al. (2011). Because the sledge cannot be safely lowered on hard substrates, transects that were located on such substrates were performed. In addition, due to time constraints, the most southern parts of the Grande Vasière were not sampled (Fig. 2). The sledge was equipped with a CTD (Conductivity, Temperature, Depth) and a GPS (Global Positioning System) devices providing the depth and geographic position 
respectively, as well as two lasers spaced $0.75 \mathrm{~m}$ apart that were calibrated to ensure a consistent field of view for analysis. Transects were on average $197.6 \mathrm{~m} \mathrm{( \pm}$ 58.50 SD.) long for an average sample area of $143.9 \mathrm{~m}^{2}( \pm 28.45 \mathrm{SD}$.).

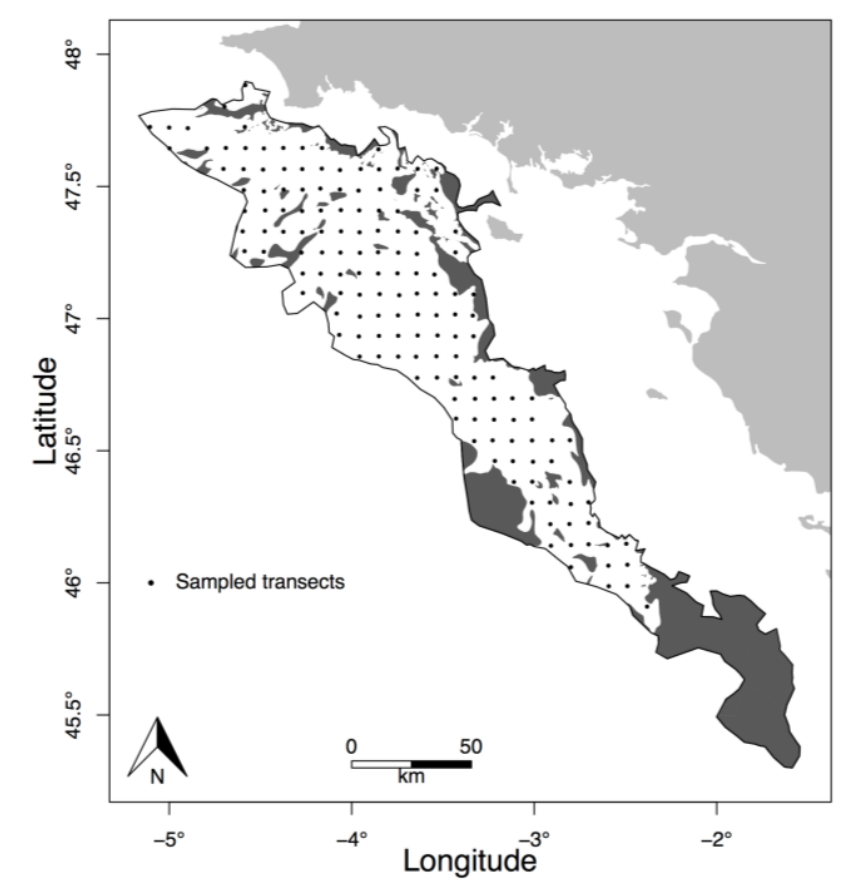

Figure 2 : Location of the sampled transect (black dots). The area in dark grey were not sampled in 2014.

Individuals were identified to the lowest possible taxonomic level and summed to get the total abundance at each transect. For taxa that could not be identified to species level, higher levels of taxonomic identification were used, such as genus, family or class. Abundances were divided by the area sampled to obtain a standardized value per $\mathrm{m}^{2}$, hereafter referred to as density.

\subsection{Fishing intensity}

Fishing effort in hours, obtained from VMS data, was used as a proxy of fishing intensity. Access to these data was provided by the French Directorate of Maritime Fisheries and Aquaculture (Direction des pêches maritimes et de l'aquaculture DPMA) and data were processed with the SACROIS algorithm (Demaneche et al. 2010), which filters VMS data to select records assumed to correspond to fishing 
activity, based on vessel speeds (< 4.5 knots) and the distance to the nearest port. We chose to use fishing intensity at 3 min longitude $\times 3$ min latitude because this was the closest available resolution to the one of the biological data grid used $(8.7 \times 8.7$ $\mathrm{km})$.

We requested extraction of VMS data for the Nephrops fishing season which covers the period from the beginning of April to the end of September, for the year 2014 . Fishing hours were summed over this period in each 3 min longitude $\times 3$ min latitude grid cell. Bottom otter trawl and otter twin trawl are the main métiers (i.e. fishing activities) in the Grande Vasière, where they accounts for $89.7 \%$ of the total fishing hours during this period (Fig. 1F). The remaining fishing hours can be divided between two métiers: gillnets and trammel nets on the one hand and other minority métiers (Danish seine, pelagic pair trawling and pelagic otter trawling) on the other hand, accounting for $5.5 \%$ and $4.8 \%$ respectively of the total fishing hours during this period, respectively (Fig. $1 \mathrm{G}$ and $1 \mathrm{H}$ ). Trawling intensity, netting intensity and other fishing intensity variables of minority métiers will hereafter be referred to as fishing variables. Fishing intensity value was extracted for each transect with a spatial join under QGIS 2.12.1-Lyon.

\subsection{Diversity indices}

For each transect, we quantified taxonomic richness as the number of observed taxa identified at the finest taxonomical level; as well as diversity and evenness using Shannon-Weaver and Pielou's indices (Pielou 1966). The Shannon-Weaver diversity index $\mathrm{H}^{\prime}$ is calculated as: $H^{\prime}=-\sum_{i=1}^{S} p_{i} \log _{2} p_{i}$, where $p_{i}$ is the proportion of the density of the $i^{\text {th }}$ taxon on a transect containing $S$ taxa. Pielou evenness $J$ ' is expressed as: $J^{\prime}=H^{\prime} / \log _{2} S$, with notations as previously defined. Pielou evenness 
is independent of the number of taxa and is only influenced by the distribution of individuals among taxa. Taxonomic richness, density (see section 2.2) and diversity indices were mapped using interpolation among transects with the Inverse Distance Weighting interpolation method under QGIS (version 2.12.1-Lyon). Spearman rank order correlation was calculated to assess the link between these diversity variables and environmental variables.

2.5. Identifying structure, spatial distribution and drivers of communities

Disentangling the interrelated effects of environmental parameters and fishing activities in areas that have been fished for decades is complicated (Pommer et al. 2016). To test the environmental and fishing effects on the distribution of the different communities while partialing out their interaction, we used a Redundancy Analysis (RDA) on Hellinger-standardized data (Borcard, Gillet and Legendre 2011). Latitude, longitude, their quadratic terms, and the latitude $\times$ longitude interaction were included in the model to account for spatial distribution of taxa density patterns (Moran's I = $0.58, p$-value $=0.001)$. Collinearity amongst environmental (depth and current speed on the seabed), fishing intensity and geographical variables (latitude, longitude, their quadratic terms, and the latitude $\times$ longitude interaction) was investigated with the variance inflation factor (VIF) and a released threshold of VIF $>10$. We decided to exclude temperature and salinity from the variables susceptible to influence community structure because of the very narrow range covered by the values of these variables on the Grande Vasière $\left(12.1-13.3^{\circ} \mathrm{C}\right.$ and $35.2-35.7 \mathrm{psu}$, respectively) that are thus unlikely to influence taxa distribution. The best RDA model was then selected by a stepwise selection using the function ordiR2step, from the vegan package (Oksanen 2011). The K-means clustering algorithm was used to 
cluster transects according to their RDA scores and the silhouette routine was applied to determine the optimal number of clusters (Rousseeuw 1987). Clusters were then characterized based on abiotic and biotic variables present in the best RDA model with the function catdes from the FactorMineR package (Husson et al. 2017). Indicator taxa of each cluster were determined using the Species Indicator Value IndVal (Dufrene and Legendre 1997). A taxon is defined as an indicator taxon of a cluster if it has both a high degree of specificity (the taxon is found only in one cluster) and fidelity (the taxon is present in all transects of the cluster) (Dufrene and Legendre 1997). The a posteriori statistical significance was assessed by a Monte Carlo permutation test.

\section{RESULTS}

\subsection{Diversity patterns}

A total of 15119 individuals belonging to 39 taxa were observed over the area: nineteen fish taxa, seven crustacean taxa, five cnidarian taxa, three mollusc taxa, three echinoderm taxa and two polychaete taxa. The number of taxa observed at any given transect varied between two and 14. Ten taxa were encountered in one or two transects while three were sampled in more than 100 transects: small unidentified (unid.) Actinopterygii, Pennatulacea and Hydrozoa (Fig. 3). 


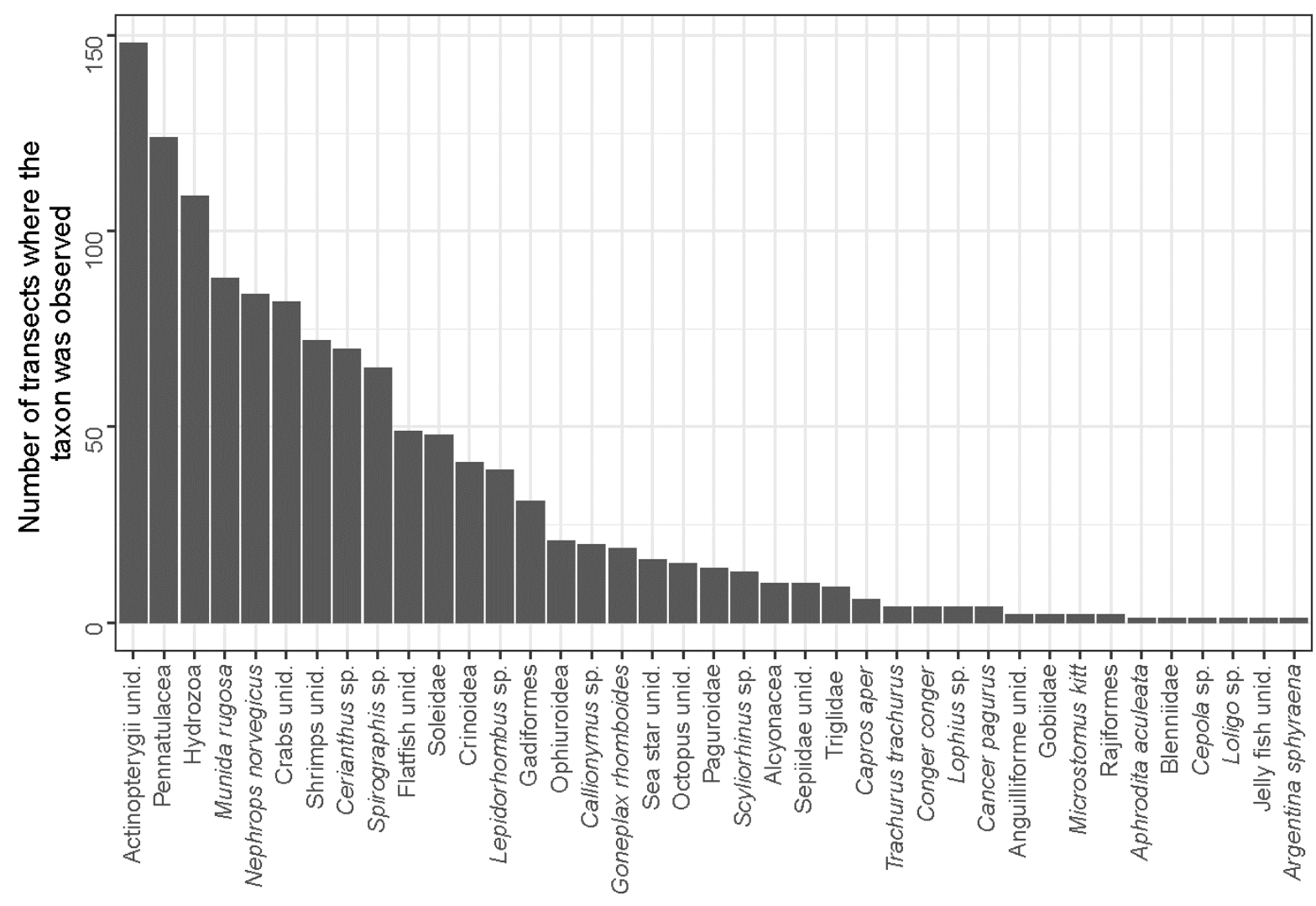

Taxa

Figure 3: Histogram of the number of transects where each taxon was observed

The highest levels of taxonomic richness were often observed on transects located on the external margins of the area (Fig. 4). These transects harboured significantly more of the following taxa: Cerianthus sp., Lepidorhombus sp., crabs unid., shrimps unid., crinoids, Gadiformes, Ophiuroidea, Pennatulacea, flatfish unid., Scyliorhinus sp. and Soleidae. For all taxa together, density ranged from 0.05 to 9.46 individuals. $\mathrm{m}^{-2}$. The taxa with the highest density were crinoids, Hydrozoa, small Actinopterygii unid. and Munida rugosa. In particular, the high density observed on the external margin was related to the high number of crinoids in this part of the Grande Vasière (Fig. 4). Shannon diversity ranged from 0.11 to 2.29 and Pielou evenness ranged from 0.05 to 0.96 . Their lowest values were found on the external margin, where crinoids strongly dominated the community. 
Taxonomic richness, density and diversity indices were weakly but significantly correlated with environmental and trawling intensity variables (Table 1). Taxonomic richness and density were positively correlated with depth, salinity and current, and negatively with trawling intensity (Table 1 ). The highest taxonomic richness was found on carbonated and calcareous muddy sands (9.05 and 9.00 taxa on average, respectively) then on lithoclastic muddy sands and sandy muds (7.83 and 7.74 taxa on average, respectively) and on muds (5.00 taxa on average). Similarly, the highest density was found on carbonated muddy sands (1.26 ind. $\mathrm{m}^{-2}$ on average) then on lithoclastic muddy sands, calcareous muddy sands, sandy muds and muds (0.63 ind. $\mathrm{m}^{-2}, 0.44$ ind. $\mathrm{m}^{-2}, 0.32$ ind. $\mathrm{m}^{-2}$ and 0.14 ind. $\mathrm{m}^{-2}$ on average, respectively). Unlike taxonomic richness and density, Pielou index was negatively correlated with depth, salinity and current and positively correlated with trawling intensity.

Taxonomic richness was positively correlated with Shannon index (rho $=0.472, p$ value $<0.0001)$ and not correlated with Pielou index (rho $=0.032, \mathrm{p}$-value $=0.699$ ) Shannon and Pielou indices were strongly correlated (rho $=0.845$, $p$-value $<0.0001$ ). Density, however, was negatively correlated with Shannon (rho $=-0.517$, p-value $<$ $0.0001)$ and Pielou (rho $=-0.763, p$-value $<0.0001)$ indices. Taxonomic richness and density were slightly positively correlated $(r h o=0.253, p$-value $=0.002)$.

Table 1: Spearman correlation (rho) between taxonomic richness, density, Shannon and Pielou indices and environmental/ fishing variables.

\begin{tabular}{|c|c|c|c|c|}
\hline & Taxonomic richness & Density & Shannon & Pielou \\
\hline Depth & $0.277^{\star}$ & $0.366^{* \star *}$ & -0.142 & $-0.326^{\star * *}$ \\
\hline Latitude & -0.040 & $-0.226^{*}$ & 0.133 & $0.193^{*}$ \\
\hline Longitude & -0.142 & 0.038 & -0.092 & -0.053 \\
\hline Temperature & 0.079 & $0.257^{\star}$ & -0.106 & $-0.184^{*}$ \\
\hline Salinity & $0.381^{\star \star *}$ & $0.320^{\star * \star}$ & -0.043 & $-0.240^{*}$ \\
\hline Current & $0.351^{* * *}$ & $0.286^{* *}$ & -0.014 & $-0.183^{*}$ \\
\hline Trawling intensity & $-0.322^{\star \star *}$ & $-0.370^{* \star *}$ & $0.163^{*}$ & $0.372^{\star * *}$ \\
\hline Netting intensity & 0.074 & -0.09 & 0.148 & 0.054 \\
\hline Other métiers fishing intensity & -0.003 & -0.01 & -0.029 & -0.020 \\
\hline
\end{tabular}

${ }^{*}: p<0.05 ;{ }^{* *}: p<0.001 ;{ }^{* \star *} p<0.0001$ 

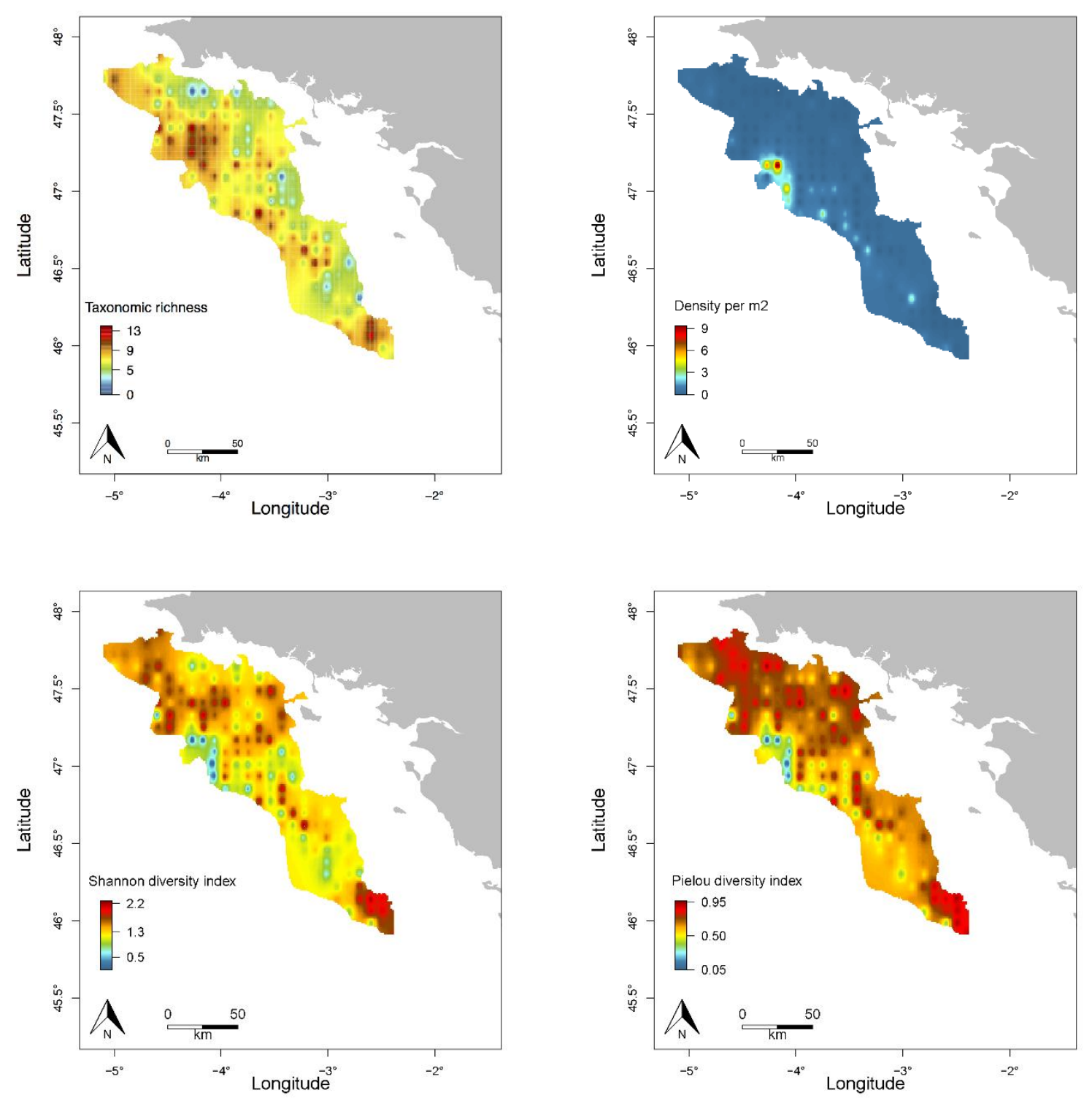

Figure 4: Spatial distribution of taxonomic richness, density of taxa per $\mathrm{m}^{2}$, and Shannon and Pielou indices. Values were recorded on each transect and interpolated for representation purposes only.

\subsection{Community structure}

The best RDA model selected included depth, current, sediment type, trawling intensity and other métiers fishing intensity and enabled to explain $20.1 \%$ of the total variance. The first two RDA axes accounted for $47.4 \%$ and $26.3 \%$ of the variability explained, respectively. Only taxa having a correlation with one of the two first axes $>3 \%$ were represented. The first axis had a strong correlation with trawling intensity (0.792), depth (0.674), current speed (0.664), sandy mud (-0.574) and carbonated 
muddy sand (0.376), while the second axis was correlated with depth $(-0.542)$, calcareous muddy sand (0.249), lithoclastic muddy sand (-0.245), mud and fishing intensity of the other métiers $(-0.179)$.

The silhouette method indicated that four was the optimal number of clusters of transects. Transects of clusters 1 and 2 were all characterized by high trawling intensity and were inhabited by small and mobile taxa (small Actinopterygii unid., shrimps unid., crabs unid., Goneplax rhomboides for cluster 1, and Munida rugosa and Nephrops norvegicus for cluster 2) (Fig. 5 and Table 2). They were separated into the two clusters according to their environmental features: transects from cluster 1 were located on calcareous muddy sands and muds, in low depth areas while most transects from cluster 2 occurred on sandy muds, with slightly lower values of current speed than the mean over the whole area. Transects in cluster 2 were also characterized by a fishing intensity of other métiers slightly higher than the mean over the whole area. Inversely, transects in clusters 3 and 4 had low fishing intensity. Transects within cluster 3, whose indicator taxon was Hydrozoa, were usually sampled on lithoclastic muddy sands and underwent low other métiers fishing intensity. Finally, cluster 4 gathered transects characterized by carbonated muddy sands and located in the deepest part of the Grande Vasière, where current speed values are among the highest in the area. The indicator taxa were crinoids, Capros aper and Octopus unid. Fauna was dominated by crinoids, accounting for $90 \%$ of the density for this cluster. 


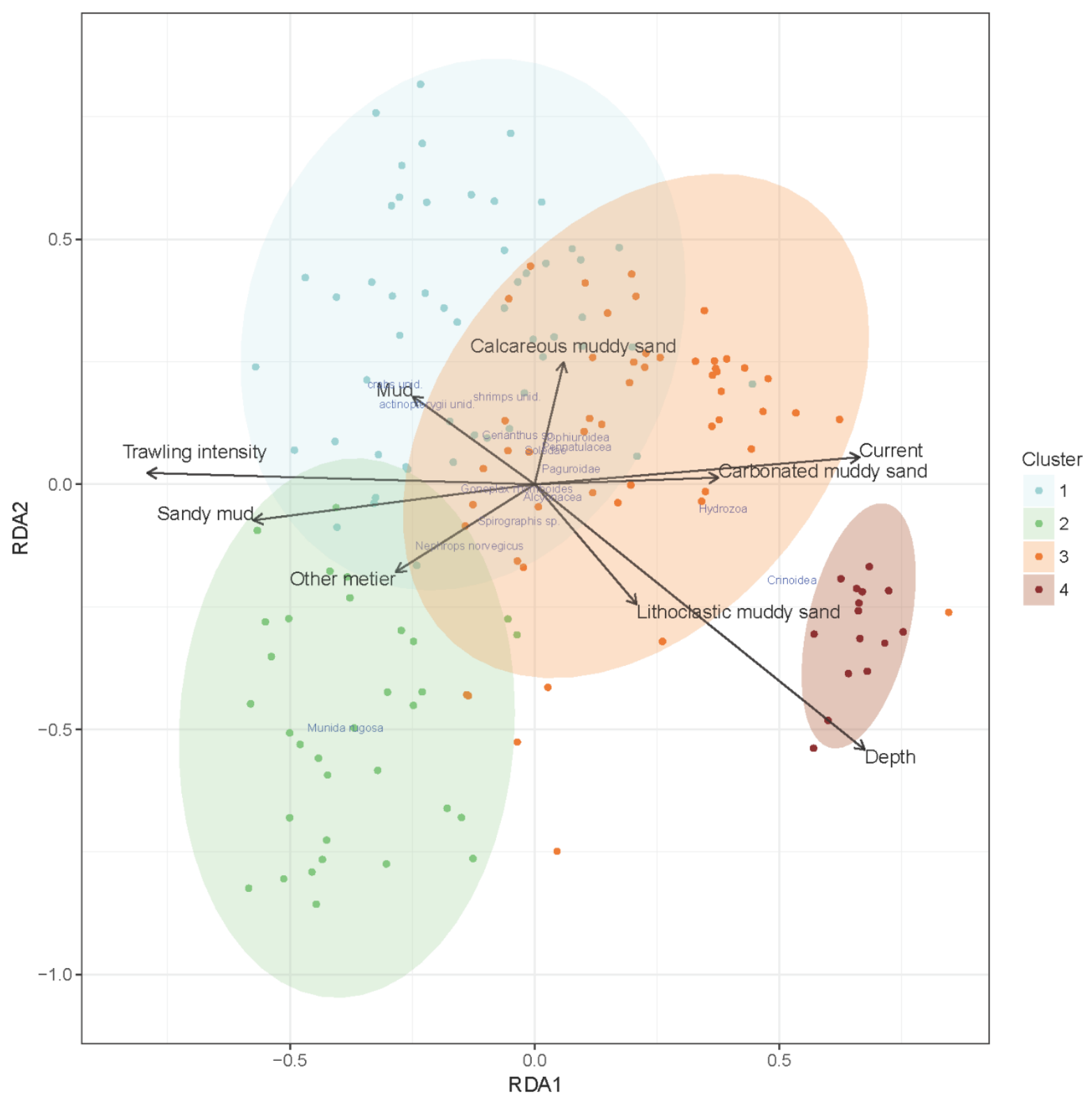

Figure 5: Redundancy analysis plot on density of taxa constrained by significant environmental and fishing intensity variables 
Table 2: Indicator taxa and environmental conditions clustered using $K$-means partitioning. For each cluster, variable values are indicated only if their mean value in one cluster is significantly different from their mean value for all clusters. In the IndVal output, indicator species presented have $p$-value $<0.05$ in the Monte Carlo permutation test.

\begin{tabular}{|c|c|c|c|c|}
\hline $\begin{array}{l}\text { Variables } \\
\text { (mean values) } \\
\end{array}$ & $\begin{array}{l}\text { Cluster } 1 \\
52 \text { transects } \\
\end{array}$ & $\begin{array}{l}\text { Cluster } 2 \\
33 \text { transects }\end{array}$ & $\begin{array}{l}\text { Cluster } 3 \\
52 \text { transects }\end{array}$ & $\begin{array}{l}\text { Cluster } 4 \\
15 \text { transects }\end{array}$ \\
\hline Sediment type & $\begin{array}{l}\text { Mud } \\
\mathrm{p} \text {-value }=1.7 \cdot \mathrm{e}^{-2} \\
\text { Calcareous muddy } \\
\text { sand } \\
\mathrm{p} \text {-value }=1.9 \cdot \mathrm{e}^{-2}\end{array}$ & $\begin{array}{l}\text { Sandy mud } \\
p \text {-value }=3.5 . e^{-3}\end{array}$ & $\begin{array}{l}\text { Lithoclastic muddy } \\
\text { sand } \\
\text { p-value }=1.1 . \mathrm{e}^{-3}\end{array}$ & $\begin{array}{l}\text { Carbonated muddy } \\
\text { sand } \\
\text { p-value }=1.9 . e^{-3}\end{array}$ \\
\hline $\begin{array}{l}\text { Depth } \\
(108 \mathrm{~m})\end{array}$ & $\begin{array}{l}\text { Lower }(104 \mathrm{~m}) \\
\mathrm{p} \text {-value }=7.2 . \mathrm{e}^{-4}\end{array}$ & & & $\begin{array}{l}\text { Higher }(122 \mathrm{~m}) \\
\mathrm{p} \text {-value }=1.8 \cdot \mathrm{e}^{-5}\end{array}$ \\
\hline $\begin{array}{l}\text { Current speed } \\
\left(0.104 \mathrm{~m}^{-1} \mathrm{~s}^{-1}\right)\end{array}$ & & $\begin{array}{l}\text { Lower }\left(0.097 \mathrm{~m}^{-1}\right) \\
\mathrm{p} \text {-value }=1.9 \cdot \mathrm{e}^{-2}\end{array}$ & & $\begin{array}{l}\text { Higher }\left(0.118 \mathrm{~m} \cdot \mathrm{s}^{-1}\right) \\
\mathrm{p} \text {-value }=2.1 . \mathrm{e}^{-3}\end{array}$ \\
\hline $\begin{array}{l}\text { Trawling intensity } \\
(256 \mathrm{~h})\end{array}$ & $\begin{array}{l}\text { Higher }(319 \mathrm{~h}) \\
\mathrm{p} \text {-value }=3.2 . \mathrm{e}^{-2}\end{array}$ & $\begin{array}{l}\text { Higher }(381 \mathrm{~h}) \\
\mathrm{p} \text {-value }=1.7 . \mathrm{e}^{-3}\end{array}$ & $\begin{array}{l}\text { Lower }(179 \mathrm{~h}) \\
\mathrm{p} \text {-value }=7.4 . \mathrm{e}^{-3}\end{array}$ & $\begin{array}{l}\text { Lower }(35 \mathrm{~h}) \\
\mathrm{p} \text {-value }=7.4 . \mathrm{e}^{-3}\end{array}$ \\
\hline $\begin{array}{l}\text { Other métiers fishing } \\
\text { intensity } \\
(7.62 \mathrm{~h})\end{array}$ & & $\begin{array}{l}\text { Higher }(12.3 \mathrm{~h}) \\
\mathrm{p} \text {-value }=2.6 \cdot \mathrm{e}^{-3}\end{array}$ & $\begin{array}{l}\text { Lower }(3.7 \mathrm{~h}) \\
\mathrm{p} \text {-value }=1.2 . \mathrm{e}^{-2}\end{array}$ & \\
\hline $\begin{array}{l}\text { Indicator species } \\
\text { IndVal }\end{array}$ & $\begin{array}{l}\text { Actinopterygii unid. } \\
\text { Shrimps unid. } \\
\text { Crabs unid. } \\
\text { Goneplax } \\
\text { rhomboides }\end{array}$ & $\begin{array}{l}\text { Munida rugosa } \\
\text { Nephrops norvegicus }\end{array}$ & Hydrozoa & $\begin{array}{l}\text { Crinoidea } \\
\text { Capros aper } \\
\text { Octopus unid. }\end{array}$ \\
\hline
\end{tabular}

The spatial clustering of transects revealed different ecosystems. Transects belonging to cluster 1 were located in the extreme south and north while transects from clusters 2 and 3 were mingled in the central part of the Grande Vasière. Transects from cluster 4 were tightly spatially clustered on the external margin of the area (Fig. 6). 


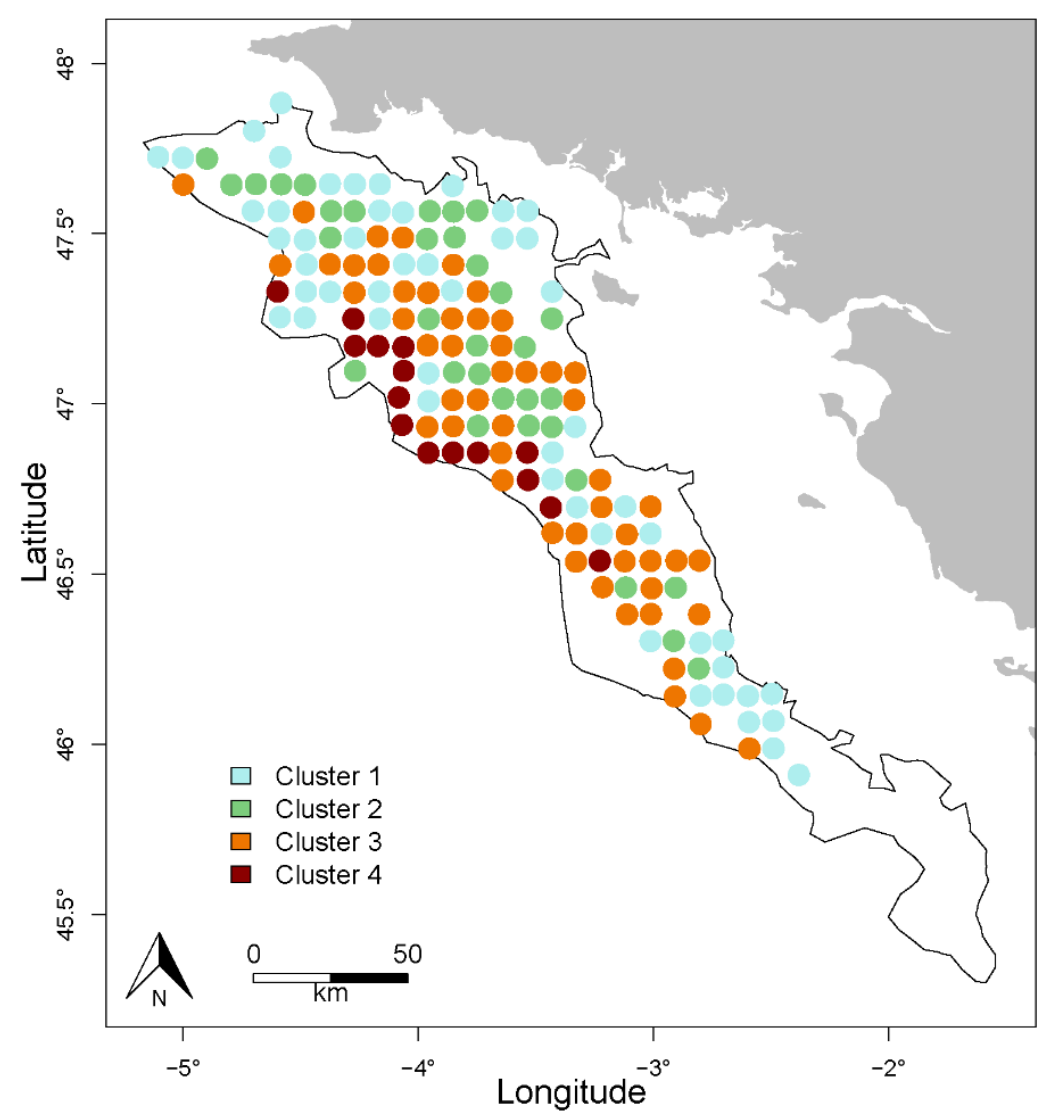

Figure 6: Transects clustered using k-means.

\section{DISCUSSION}

\subsection{General trends of diversity patterns in the Grande Vasière}

In the present study, we established a spatially explicit assessment of diversity patterns throughout the Grande Vasière. The relationship between taxonomic richness and Shannon and Pielou indices was previously reported to be positive and strong (de Benedictis 1973; Stirling and Wilsey 2001). Our results corroborate these findings apart from the absence of correlation between richness and Pielou's evenness index. This most likely reflects the finding that transects on the external margin, which had the highest levels of taxa richness, were, in fact, dominated by a handful of taxa with very high densities (mainly crinoids but also Hydrozoa, Munida 
rugosa and small Actinopterygii unid.). Conversely, transects located along the coastline were characterized by a high diversity and a more balanced distribution of densities across taxa. Our results revealed contrasting trends between density, community structure and diversity (Pielou's evenness and Shannon index). However, as noted by Serrano et al. (2008), relationships between diversity indices and environmental and fishing variables remained weak and highlight the need for complementary indices. Depth, sediment type, current speed, trawling intensity and other métiers fishing intensity were identified as the main drivers of community structure in the Grande Vasière.

\subsection{Environmental and fishing intensity variables influence diversity patterns}

In the Grande Vasière, the combination of depth, current speed and type of sediment have a particularly structuring effect on diversity patterns. Taxonomic richness and density are the highest for transects located on carbonated and calcareous muddy sands, in areas with the highest values of depth and current speed. This increase in richness and density of epibenthic macro and megafauna with depth seems unusual compared with studies previously made over a similar depth range (Serrano et al. 2008, Martins et al. 2013). The distribution of the most abundant taxon (crinoids) in the deepest parts of the Grande Vasière most likely influences the positive trend of density with depth. The more balanced distribution of taxa in the northern part of the area, close to the coastline, could be linked to a stronger spatial heterogeneity in sediment types offering a higher diversity of ecological niches, as reported by Ellis et al. (2000) in the Irish Sea.

Fishing intensity, either trawling or other minority métiers, also significantly structured communities. An increase in fishing pressure was often related to a shift toward a 
dominance by fewer taxa (Kaiser and Spencer 1996; Ellis et al. 2000), which was not observed in this study. However, the opposite trend has also been reported. In a similar way to our study, Smith et al. (2000) recorded a positive correlation between taxonomic evenness and trawling intensity. Indeed, communities outside the trawling lane were dominated by a fragile taxon, whose dominance within the trawling lane was restricted by trawling disturbance. It thus appears that one reason for the increase of taxonomic evenness with trawling intensity could be the presence of a dominant taxon negatively influenced by trawling. The aforementioned balanced distribution of taxa in the northern part of the area could also be explained by trawling intensity. The high trawling intensity undergone by these transects could hinder the dominance of taxa negatively impacted by trawling. This is in accordance with the community homogenization observed by Hily et al. (2008) between 1966 and 2001, in relation to increasing trawling activities. In 2001, the number of distinct communities has decreased; they were also more homogenous in taxa and abundance distribution and dominated by taxa tolerant to trawling disturbance. Transects located in the central-northern part of the Grande Vasière showed the highest values of taxonomic evenness and medium to high levels of trawling intensity. This is in line with the "intermediate disturbance hypothesis" positing that diversity is highest at an intermediate level of disturbance (Petraitis et al. 1989), as well as with findings from a previous study on the Grande Vasière (Blanchard et al. 2004). The negative relationship between trawling intensity and taxonomic richness observed is also supported by the literature on muddy fishing grounds (Blanchard et al. 2004 in the Grande Vasière; Hiddink et al. 2006 in the North Sea and from models; Hinz et al. 2009 in the northern Irish Sea; Pusceddu et al. 2014 in the northwestern Mediterranean Sea). 
4.3. Environmental, fishing intensity and biological relationships drive community structure

Indicator taxa identified for each cluster of transects also supported the idea that these environmental and fishing intensity factors put constraints on the communities. In cluster 1, taxa were characteristic of coastal muddy detritic biocoenosis (Martins et al. 2013) as illustrated by the presence of Goneplax rhomboides, which needs muddy sediments for digging burrows. Likewise, indicator species of cluster 2, Nephrops norvegicus and Munida rugosa, rely on sandy mud and mud to build their burrows in soft sediments with a specific silt-clay ratio (Campbell et al. 2009, Johnson et al. 2013). Transects in these two clusters experienced high fishing intensity (trawling and, in the case of cluster 2, other métiers) and included mobile and opportunistic scavengers, which can feed on dead or damage organisms and have a low vulnerability to trawling (de Juan and Demestre 2012).

The influence of environmental conditions on community structure was particularly strong for transects within cluster 4 . These transects were characterized by the presence of two taxa, found on deep sandy beds, Capros aper and crinoids, the latter being filter feeders dependant on currents for their food supply (Glémarec 1969; Serrano et al. 2008; Hily et al. 2008). Clusters 3 and 4 gathered transects characterised by low fishing intensity and the occurrence of attached sessile filter feeders, whose fragile structure can be broken by towed gears and filtering organs clogged by the re-suspended sediments (Jennings and Kaiser 1998). These results corroborated patterns observed in other studies on the impacts of trawling activities on the seabed (Bremner et al 2006; Tillin et al. 2006; Thrush and Dayton 2010; de Juan and Demestre 2012). 


\subsection{Interrelated structuring effects}

Although fishing intensity and environmental parameters are significant drivers of community structure in the Grande Vasière, we can hardly disentangle their pure effect as driving factors. The highest trawling intensity was recorded on muds and shallower areas whereas the lowest intensity was recorded on muddy sands and deeper areas. It is thus impossible to decipher whether the distribution of crinoids was gradually restricted to the less trawled areas due to their vulnerability to trawling disturbance or if their distribution was caused by their sedimentary or current speed preferences. Similarly, burrowing and opportunistic scavengers, like Nephrops norvegicus and Munida rugosa, are also competitive predators occurring in nonimpacted ecosystems (Vergnon and Blanchard 2006) and thus are not always markers of intensive trawling activities.

It is thus not possible to conclude whether fishing activities shaped the distribution of communities or fishing took place in areas with a high density of commercial taxa and low density of large sessile epifauna. A reference state would be needed to evaluate human impact on both communities and physical habitats. The Grande Vasière has been fished for a century with an increased intensity since the end of World War II (Guénette and Gascuel 2012). Any decline in the abundance of vulnerable taxa might have occurred before modern monitoring (Roberts 2010). Ecosystems are most likely adapted to this physical disturbance (Kaiser et al. 2000, Greathead et al. 2007), as are communities subject to strong currents or storm waves (Watling and Norse 1998). Glémarec's 1969 study does not thus provide an insight into a pristine state, but still offers a point of comparison. Hily et al. (2008) subsequently re-sampled the same transects as in Glémarec's study and brought some insights on the recent 
evolution of the ecosystem, i.e. characterized by a decrease in the number of distinct communities as well as an increased dominance of the fine sand fraction. Changes in the sediment composition were interpreted as resulting from the joint action of fishing activities and currents (Mengual et al. 2016) but could also be related to a decrease in the annual fluvial sediment flux to the ocean (J.F. Bourillet, pers. comm.). Further analyses are needed to conclude on the drivers of changes in the structure of communities (e.g. changes in habitat, direct impact of fishing or other environmental variables...).

\subsection{Comparisons with previous studies are limited by sampling methods}

There are some similarities among the communities identified here and those observed in previous studies. In particular, two main communities can be distinguished: i) one, on sandy mud sediments within the limits of the Grande Vasière, dominated by Hydrozoa, small unid. Actinopterygii and Munida rugosa; and ii) another characterised by the presence of crinoids and located in the external margin, on muddy sand rich in $\mathrm{CaCO}_{3}$ (i.e., carbonated mud) (Glemarec 1969; Hily et al. 2008; Le Loc'h et al. 2008). Yet our results provide a finer description, with the clustering of the biodiversity within the Grande Vasière into three distinct clusters (i.e., clusters 1, 2 and 3). We also noticed that the distribution of crinoids appeared to be stable through time. Conversely, Pennatulacea, previously reported to be very rare (Hily et al. 2008), occurred in 124 out of the 152 transects sampled in our study This discrepancy among studies is likely due to the sampling devices used, since Pennatulacea are very poorly sampled by trawls or dredges.

The comparison of our observations with previous studies is mainly limited by differences in sampling methods. The use of underwater video methodology does not 
allow individual biomass to be measured, impedes the identification of individuals to the highest taxonomic level, and prevents identification of very small individuals $(<2$ $\mathrm{cm}$ ) or those buried in the sediment (see Mérillet et al. 2017 for more information on the limitations of underwater video). In contrast, grab or box corers enable good sampling of benthic infauna $(<2 \mathrm{~cm})$ and a beam trawl can be successfully used to sample macro and mega fauna $(>2 \mathrm{~cm})$ in the upper part of the sediment (BuhlMortensen et al. 2015). However, the efficiency of a given traditional sampling device differs from one sediment to another. An increasing level of coarse particles or of clay particles consolidates the sediment and hinders the retrieval of grab samples (BuhlMortensen et al. 2015). Likewise, rocky areas cannot be sampled using a beam trawl. Underwater video offers the opportunity to observe an entire habitat and the fragile species that would be broken by traditional sampling methods. It also provides a better assessment of densities and patchiness than the other sampling methods (Buhl-Mortensen et al. 2015). The combination of several sampling methods might be the best solution for an accurate assessment of biodiversity and the status of benthic habitats.

\section{CONCLUSION}

The use of underwater video and the large coverage of this study offered new insights into diversity patterns in the Grande Vasière and, in particular, on the occurrence of fragile taxa that are difficult to sample. Compared to previous biodiversity assessments on the area, we were also able to better differentiate communities and their links with environmental and fishing conditions, despite the fact that not all individuals could be identified to the species level. This study still provides a snapshot of the distribution of epifauna that could, for instance, be used 
as a reference point to assess the evolution of rare and vulnerable species. A proper time series would be essential in order to evaluate temporal and seasonal variations. In particular, it would be necessary to follow the evolution of the sediments, as Hily et al. (2008) noticed that an increase of the sand fraction and a homogenization of sediments had occurred since the study of Glémarec (1969). Such changes in the seabed would eventually lead to a homogenization of communities and threaten the spatial expansion of taxa depending on fine mud, such as Nephrops. Underwater video could provide a first assessment of benthic habitats as it allows the visualization of the seabed and any possible damage it has suffered, such as trawl marks, derelict fishing gears or waste. In the context of spatial planning development, it is particularly important to know the composition and the distribution of communities, as well as the state of preservation of the seabed, to provide easily accessible and understandable information to managers.

\section{ACKNOWLEDGEMENTS}

This work was part of the TETRIS project supported by France Filière Pêche. The authors are very grateful to the National Committee for Maritime Fisheries and Fish Farming (CNPMEM) and to the French Directorate of Marine Fisheries and Aquaculture (DPMA) who accepted to provide the VMS data to the team from the French Fisheries Information System (SIH) who processed the data. All data used were aggregated so that the confidentiality of vessels was not compromised. We would like to thank the LANGOLF-TV team for the video acquisition, and the crew of the R/V Celtic Voyager and staff of the Marine Institute of Ireland for their contribution to the data collection. We also thank Mickaël Vasquez (IFREMER-DYNECO-LEBCO) 
for data extraction from the MARS3D model and J.F. Bourillet (IFREMER-REM) for providing information on the evolution of the sediments in the Grande Vasière.

\section{REFERENCES}

Auster, P.J., Gjerde, K., Heupel, E., Watling, L., Grehan, A., Rogers, A.D., 2011. Definition and detection of vulnerable marine ecosystems on the high seas : problems with the " move-on " rule. ICES J. Mar. Sci. 68, 254-264.

Blanchard, F., LeLoc'h, F., Hily, C., Boucher, J., 2004. Fishing effects on diversity, size and community structure of the benthic invertebrate and fish megafauna on the Bay of Biscay coast of France. Mar. Ecol. Prog. Ser. 280, 249-260. doi:10.3354/meps280249

Bouysse, P., Lesueur, P., Klingebiel, A., 1986. Carte des sédiments superficiels du plateau continental du Golfe de Gascogne: partie septentrionale au 1/500.000. co-éditée par BRGM et IFREMER. http://sextant.ffremer.fr/record/ea0b61b071c6-11dc-b1e4-000086 f6a62e/. Accessed 8 february 2016

Borcard, D., Gillet, F., Legendre, P., 2011. Numerical Ecology with R, Springer. ed. Springer, New York. https://doi.org/10.1007/978-1-4419-7976-6

Bremner, J., Rogers, S.I., Frid, C.L.J., 2006. Matching biological traits to environmental conditions in marine benthic ecosystems. J. Mar. Syst. 60, 302316. doi:10.1016/j.jmarsys.2006.02.004 
Buhl-Mortensen, L., Buhl-Mortensen, P., Dolan, M.J.F., Gonzalez-Mirelis, G., 2015. Habitat mapping as a tool for conservation and sustainable use of marine resources: Some perspectives from the MAREANO Programme, Norway. J. Sea Res. 100, 46-61. doi:10.1016/j.seares.2014.10.014

Campbell, N., Allan, L., Weetman, A., Dobby, H., 2009. Investigating the link between Nephrops norvegicus burrow density and sediment composition in Scottish waters. ICES J. Mar. Sci. 66, 2052-2059. doi:10.1093/icesjms/fsp176

de Benedictis, P. A. 1973. On the correlations between certain diversity indices. American Naturalist 107:295-302.

de Juan, S., Demestre, M., 2012. A Trawl Disturbance Indicator to quantify large scale fishing impact on benthic ecosystems. Ecol. Indic. 18, 183-190. doi:10.1016/j.ecolind.2011.11.020

Demaneche, S., Begot, E., Gouello, A., Habasque, J., Merrien, C., Leblond, E., Berthou, P., Harscoat, V., Fritsch, M., Leneveu, C., Laurans, M., 2010. Projet SACROIS "IFREMER/DPMA" - Rapport final - Convention SACROIS 2008-2010. URL http://sih.ffremer.fr/Description-des-donnees/Donnees-estimees/SACROIS

Dufrene, M., Legendre, P., 1997. Species assemblages and indicator species: the need for a flexible asymmetrical approach. Ecol. Monogr. 67(3):345-366. 
Eigaard, O.R., Bastardie, F., Breen, M., Dinesen, G., Hintzen, N.T., Laffargue, P., Mortensen, L.O., Nielsen, J.R., Nilsson, H.C., O’Neill, F.G., Polet, H., Reid, D.G., Sala, A., Sköld, M., Smith, C., Sorensen, T.K., Tully, O., Zengin, M., Rijnsdorpa, A.D., 2016. Estimating seabed pressure fromdemersal trawls, seines, and dredges based on gear design and dimensions. ICES J. Mar. Sci. 73, 27-43. doi:10.1093/icesjms/fst176

Ellis, J.R., Rogers, S.I., Freeman, S.M., 2000. Demersal Assemblages in the Irish Sea, St George's Channel and Bristol Channel. Estuar. Coast. Shelf Sci. 51, 299-315. doi:10.1006/ecss.2000.0677

Glémarec, M., 1969. Le Plateau Continental Nord-Gascogne Et La Grande Vasière Etude Bionomique. Rev. Trav. Inst. Pêches marit. 33, 301-310.

Gray, J.S., Dayton, P., Thrush, S., Kaiser, M.J., 2006. On effects of trawling, benthos and sampling design. Mar. Pollut. Bull. 52, 840-843. doi:10.1016/j.marpolbul.2006.07.003

Greathead, C., Donnan, D. W., Mair, J. M., Saunders, G. R., 2007. The sea pens Virgularia mirabilis, Pennatula phosphorea and Funiculina quadrangularis: Distribution and conservation issues in Scottish waters. J. Mar. Biol. Ass. U.K., 87, 1095-1103. https://doi.org/10.1017/S0025315407056238 
Guénette, S., Gascuel, D., 2012. Shifting baselines in European fisheries: The case of the Celtic Sea and Bay of Biscay. Ocean Coast. Manag. 70, 10-21. doi:10.1016/j.ocecoaman.2012.06.010

Hewitt, J., Julian, K., Bone, E.K., 2011. Chatham-Challenger Ocean Survey 20/20 Post-Voyage Analyses: Objective 10 - Biotic habitats and their sensitivity to physical disturbance. New Zealand Aquatic Environment and Biodiversity Report No. 81 .

Hiddink, J.G., Jennings, S., Kaiser, M.J., Queiros, a. M., Duplisea, D.E., Piet, G.J., 2006. Cumulative impacts of seabed trawl disturbance on benthic biomass, production and species richness in different habitats. Can. Jouirnal Fish. Aquat. Sci. 63, 721-736. doi:10.1139/f05-266

Hily, C., Le Loc'h, F., Grall, J., Glémarec, M., 2008. Soft bottom macrobenthic communities of North Biscay revisited: Long-term evolution under fisheriesclimate forcing. Estuar. Coast. Shelf Sci. 78, 413-425. doi:10.1016/j.ecss.2008.01.004

Hinz, H., Prieto, V., Kaiser, M.J., 2009. Trawl disturbance on benthic communities: Chronic effects and experimental predictions. Ecol. Appl. 19, 761-773. doi:10.1890/08-0351.1

Husson, F., Josse, J., Le, S.,Maze J., 2017. FactoMineR. Version 1.35. (https://cran.r-project.org/web/packages/FactoMineR) 
ICES, 2016. ICES WGDEC REPORT 2016 Report of the Joint ICES / NAFO Working Group on Deep-water Ecology ( WGDEC ) International Council for the Exploration of the Sea. Copenhagen.

Jennings, S., Kaiser, M.J., 1998. The Effects of Fishing on Marine Ecosystems, in: Advances in Marine Biology. pp. 201-352. doi:10.1016/S0065-2881(08)60212-6

Johnson, M.P., Lordan, C., Power, A.M., 2013. Habitat and Ecology of Nephrops norvegicus, 1st ed, Advances in Marine Biology. Elsevier Ltd. doi:10.1016/B978$0-12-410466-2.00002-9$

Kaiser, M.J., Ramsay, K., Richardson, C.A., Spence, F.E., Brand, A.R., 2000. Chronic fishing disturbance has changed shelf sea benthic community structure. J. Anim. Ecol. 69, 494-503. doi:10.1046/j.1365-2656.2000.00412.x

Kaiser, M.J., Spencer, B.E., 1996. The effects of beam-trawl disturbance on infaunal communities in different habitats. J. Anim. Ecol. 65, 348-358.

Lazure, P., Garnier, V., Dumas, F., Herry, C., Chifflet, M., 2009. Development of a hydrodynamic model of the Bay of Biscay. Validation of hydrology. Continental Shelf Research 29: 985-997.

Le Loc'h, F., Hily, C., Grall, J., 2008. Benthic community and food web structure on the continental shelf of the Bay of Biscay (North Eastern Atlantic) revealed by 
stable isotopes analysis. J. Mar. Syst. 72, 17-34.

doi:10.1016/j.jmarsys.2007.05.011

Lordan, C., Doyle, J., Bunn, R., Fee, D., Allsop, C., 2011. Aran, Galway Bay and Slyne Head Nephrops Grounds (FU17) 2011 UWTV Survey Report. Galway, Ireland: Marine Institute.

Mallet, D., Pelletier, D., 2014. Underwater video techniques for observing coastal marine biodiversity: A review of sixty years of publications (1952-2012). Fish. Res. 154, 44-62. doi:10.1016/j.fishres.2014.01.019

Martins, R., Quintino, V., Rodrigues, A. M., 2013. Diversity and spatial distribution patterns of the soft-bottom macrofauna communities on the Portuguese continental shelf. J. Sea Res. 83, 56-64. doi:10.1016/j.seares.2013.03.001

Mengual, B., Cayocca, F., Le Hir, P., Draye, R., Laffargue, P., Vincent, B., Garlan, T., 2016. Influence of bottom trawling on sediment resuspension in the "GrandeVasière" area (Bay of Biscay, France). Ocean Dynamics. 66, 1181-1207. https://doi.org/10.1007/s10236-016-0974-7

Mérillet, L., Kopp, D., Robert, M., Salaün, M., Méhault, S., Bourillet, J.-F., Mouchet, M., 2018. Are trawl marks a good indicator of trawling pressure in muddy sand fishing grounds? Ecol. Indic. 85, 570-574. doi:10.1016/j.ecolind.2017.11.016 
Mérillet, L., Mouchet, M., Robert, M., Salaün, M., Schuck, L., Vaz, S., Kopp, D., 2017. Using underwater video to assess megabenthic community vulnerability to trawling in the Grande Vasière (Bay of Biscay). Environ. Conserv. 1-10. doi:10.1017/S0376892917000480

Oksanen, J., 2011. Vegan: Community Ecology Package. R Package Version 2.4-3. (https://cran.r-project.org/web/packages/vegan)

Petraitis, P.S., Latham, R.E., Niesenbaum, R.A., 1989. The Maintenance of Species Diversity by Disturbance. Q. Rev. Biol. 64, 393-418. doi:10.1086/416457

Pielou, E.C., 1966. Species-Diversity and Pattern-Diversity in the Study of Ecological Succession. J. Theor. Biol. 10, 370-383.

Pommer, C., Olesen, M., Hansen, J., 2016. Impact and distribution of bottom trawl fishing on mud-bottom communities in the Kattegat. Mar. Ecol. Prog. Ser. 548, 47-60. doi:10.3354/meps11649

Poulard, J.-C., Blanchard, F., Boucher, J., Souissi, S., 2003. Variability in the demersal fish assemblages of the Bay of Biscay during the 1990s. ICES Mar. Sci. Symp. 219, 411-414.

Pusceddu, A., Bianchelli, S., Martin, J., Puig, P., Palanques, A., Masque, P., Danovaro, R., 2014. Chronic and intensive bottom trawling impairs deep-sea 
biodiversity and ecosystem functioning. Proc. Natl. Acad. Sci. 111, 8861-8866. doi:10.1073/pnas.1405454111

Roberts, C., 2010. The Unnatural History of the Sea. Washington, DC, USA: Island Press.

Rousseeuw, P.J., 1987. Silhouettes: A graphical aid to the interpretation and validation of cluster analysis. J. Comput. Appl. Math., 20, 53-65.

Sell, A.F., Kröncke, I., 2013. Correlations between benthic habitats and demersal fish assemblages - A case study on the Dogger Bank (North Sea). J. Sea Res. 80, 12-24. doi:10.1016/j.seares.2013.01.007

Serrano, A., Preciado, I., Abad, E., Sanchez, F., Parra, S., Frutos, I., 2008. Spatial distribution patterns of demersal and epibenthic communities on the Galician continental shelf (NW Spain). J. Mar. Syst. 72, 87-100. doi:10.1016/j.jmarsys.2007.05.012

Sheehan, E. V., Vaz, S., Pettifer, E., Foster, N.L., Nancollas, S.J., Cousens, S., Holmes, L., Facq, J.V., Germain, G., Attrill, M.J., 2016. An experimental comparison of three towed underwater video systems using species metrics, benthic impact and performance. Methods Ecol. Evol. 7, 843-852. doi:10.1111/2041-210X.12540 
Smith, C., Papapdopoulou, K.N., Diliberto, S., 2000. Impact of otter trawling on an eastern Mediterranean commercial trawl fishing ground. ICES J. Mar. Sci. 57, $1340-1351$.

Stirling, G., Wilsey, B., 2001. Empirical Relationships between Species Richness, Evenness, and Proportional Diversity. Am. Nat. 158, 286-299. doi:10.1086/321317

Thrush, S.F., Dayton, P.K., 2010. What Can Ecology Contribute to Ecosystem-Based Management? Annu. Rev. Mar. Sci. 2, 419-441. doi:10.1146/annurev-marine$120308-081129$

Tillin, H.M., Hiddink, J.G., Jennings, S., Kaiser, M.J., 2006. Chronic bottom trawling alters the functional composition of benthic invertebrate communities on a seabasin scale. Mar. Ecol. Prog. Ser. 318, 31-45. doi:10.3354/meps318031

Vaz, S., Carpentier, A., Coppin, F., 2007. Eastern English Channel fish assemblages: Measuring the structuring effect of habitats on distinct sub-communities. ICES J. Mar. Sci. 64, 271-287. doi:10.1093/icesjms/fsl031

Vergnon, R., Blanchard, F., 2006. Evaluation of trawling disturbance on macrobenthic invertebrate communities in the Bay of Biscay, France: Abundance biomass comparison (ABC method). Aquat. Living Resour. 19, 219-228. doi:10.1051/alr:2006022 
Watling, L., Norse, E. a, 1998. Disturbance of the Seabed by Mobile Fishing Gear: A Comparison to Forest Clearcutting. Conserv. Biol. 12, 1180-1197. doi:10.1046/j.1523-1739.1998.0120061180.x 
Supplementary material

Appendix A: List of the sampled taxa, their taxonomic level and density

\begin{tabular}{|c|c|c|}
\hline Taxa & Taxonomic level & Density \\
\hline Actinopterygii unid. & Class & 14.164 \\
\hline Alcyonacea & Order & 0.278 \\
\hline Anguilliforme unid. & Order & 0.017 \\
\hline Aphrodita aculeata & Species & 0.007 \\
\hline Argentina sphyraena & Species & 0.009 \\
\hline Blenniidae & Family & 0.006 \\
\hline Callionymus sp. & Genus & 0.198 \\
\hline Cancer pagurus & Species & 0.031 \\
\hline Capros aper & Species & 0.058 \\
\hline Cepola sp. & Genus & 0.005 \\
\hline Cerianthus sp. & Genus & 1.068 \\
\hline Conger conger & Species & 0.027 \\
\hline Crabs unid. (Brachyura) & Infraorder & 2.087 \\
\hline Crinoidea & Class & 39.442 \\
\hline Flat fish unid. (Pleuronectiformes) & Order & 0.418 \\
\hline Gadiformes & Order & 0.325 \\
\hline Gobiidae & Family & 0.016 \\
\hline Goneplax rhomboides & Species & 0.212 \\
\hline Hydrozoa & Class & 19.085 \\
\hline Jelly fish unid. (Cnidaria) & Phylum & 0.021 \\
\hline Lepidorhombus sp. & Genus & 0.405 \\
\hline Loligo sp. & Genus & 0.009 \\
\hline Lophius sp. & Genus & 0.034 \\
\hline Microstomus kitt & Species & 0.014 \\
\hline Munida rugosa & Species & 11.436 \\
\hline Nephrops norvegicus & Species & 1.831 \\
\hline Octopus unid. & Genus & 0.117 \\
\hline Ophiuroidea & Class & 0.521 \\
\hline Paguroidae & Superfamily & 0.348 \\
\hline Pennatulacea & Order & 5.364 \\
\hline Rajiformes & Order & 0.019 \\
\hline Scyliorhinus sp. & Genus & 0.114 \\
\hline Sea star unid. (Asteroidea) & Class & 0.123 \\
\hline Sepiidae unid. & Family & 0.089 \\
\hline Shrimps unid. (Decapoda) & Order & 2.451 \\
\hline Soleidae & Family & 0.523 \\
\hline Spirographis sp. & Genus & 0.867 \\
\hline Trachurus trachurus & Species & 0.153 \\
\hline Triglidae & Family & 0.058 \\
\hline
\end{tabular}

